Brit. J. industr. Med., 1951, 8, 117.

\title{
THE EFFECT OF 2-3 DIMERCAPTO-PROPANOL (BAL) ON EXPERIMENTAL NICKEL CARBONYL POISONING
}

\author{
BY \\ J. M. BARNES and F. A. DENZ \\ From the Medical Research Council Unit for Research in Toxicology, Carshalton, Surrey
}

(RECEIVED FOR PUBLICATION MARCH 21, 1951)

The experiments recorded in this paper were designed to investigate the effects of the inhalation of nickel carbonyl by rats and rabbits, and to study in detail the distribution of nickel in the body, the development of pathological lesions, and the influence of the therapeutic agent 2-3 dimercaptopropanol (BAL) on these changes. The study was made because occasional cases of accidental poisoning in man by mixtures of nickel carbonyl and carbon monoxide occur in the production of nickel by the Mond process, which entails the formation and subsequent decomposition by heat of gaseous nickel carbonyl. When the process was first developed in this country, accidental exposure to nickel carbonyl led to some fatalities and from time to time fatal accidents have been reported in other countries. No fatal accidents have occurred in Great Britain during the past 40 years, but accidental exposure due to leaks and other technical faults in the factory sometimes leads to severe and protracted illness in workmen.

The toxic material, nickel carbonyl, is a clear volatile liquid, boiling at $43^{\circ} \mathrm{C}$. Its vapour rapidly decomposes in the presence of moisture to give metallic nickel and carbon monoxide; in the presence of carbon dioxide the nickel is deposited as the suboxide. Some of the earlier writers considered that the toxic action of nickel carbonyl was due to the carbon monoxide that it liberated, but this view was effectively refuted by Armit (1907, 1908) who has made the only significant contribution to the experimental study of nickel carbonyl poisoning. Armit pointed out that nickel carbonyl had a higher toxicity than could be accounted for by its carbon monoxide moiety, and that a dose of nickel carbonyl sufficient to kill a rabbit would liberate so little carbon monoxide that only $5 \%$ of the animal's haemoglobin could be converted to carboxy-haemoglobin. In addition to the considerable pathological changes in the lung, Armit described lesions in the brain and adrenals of experimental animals and gave reasons for attributing a general systemic action to the nickel liberated from nickel carbonyl. In the present paper the way in which nickel carbonyl exerts its toxic action is reconsidered.

The effects of BAL on experimental nickel carbonyl poisoning will be considered in some detail. BAL is effective in the treatment of poisoning by arsenicals and by mercury salts, and somewhat less certainly in poisoning with the salts of lead and gold. There are grounds for believing that BAL would be effective in poisoning by nickel carbonyl. Nickel in the form of its soluble salts when added to a solution of BAL is immediately precipitated as an insoluble mercaptide. Further, Braun, Lusky, and Calvery (1946) showed that rabbits given a lethal dose of nickel sulphate by subcutaneous injection could be saved by treatment with BAL. But BAL therapy in man should be introduced with caution. BAL is itself appreciably toxic, and in addition it has been shown to increase rather than diminish the toxicity of some metals such as cadmium and uranium. The experimental studies, recorded in this paper, of the effect of BAL on nickel carbonyl poisoning will emphasize the difficulties that arise in the applications of this method of treatment of poisoning by toxic metals.

\section{Materials and Methods}

Rats and rabbits were held in wire cages and exposed in a rectangular chamber with glass windows. Fig. 1 is a diagram of the apparatus. The exposure chamber (E) of approximately 40 litres capacity was open at both ends and a current of air was drawn through at a constant rate of 30 litres per minute by means of a vacuum pump (P1) drawing air through the glass jet (A) which was made to function as a critical orifice.

Nickel carbonyl vapour was added to the air stream 


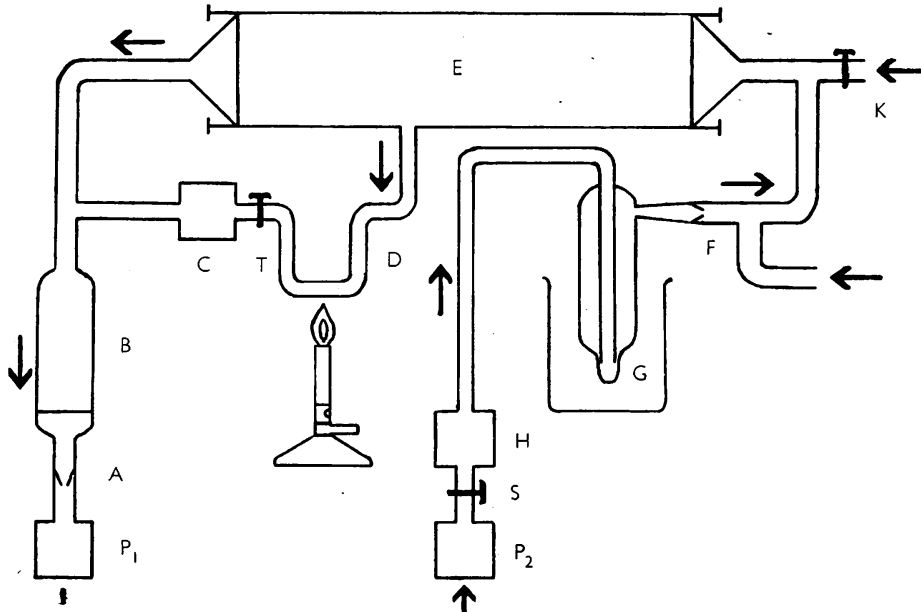

Fig. 1.-Diagram of apparatus for exposing rats and rabbits to nickel carbonyl vapour.

as it entered the chamber. A small pump (P2) delivered air at a rate measured by the flowmeter $(\mathrm{H})$ and controlled by a screw clip (S), and this air was then bubbled through liquid nickel carbonyl which was held at $0^{\circ} \mathrm{C}$. by packing the bubbler (G) with ice chips. The rate of flow through the bubbler ranged from 20 to $70 \mathrm{ml}$. per minute. The air, saturated with nickel carbonyl, was then diluted by passing through a mixing jet (F) into a volume of 10 litres per minute of air freshly drawn from the laboratory. It was diluted a second time with air entering at $(K)$ at a rate of 20 litres per minute to give a final rate of flow of $\mathbf{3 0}$ litres per minute. These successive dilutions of the small volume of air saturated with nickel carbonyl ensured thorough mixing. After passing through the chamber the air was drawn over activated charcoal in a tower (B) to free it from nickel carbonyl before it entered the evacuating pump (P1). Throughout the period of exposure, the air in the chamber was sampled by drawing off air from a tap in the chamber at a measured rate of 1 litre per minute and passing it through a heated silica tube filled with silica chips (D) in which the nickel carbonyl was decomposed and the nickel itself deposited. The volume of air forming the sample was measured by the flowmeter (C), and controlled by the screw clip (T). At the end of the exposure the deposit of nickel in the sampling tube was dissolved in nitric acid and estimated chemically. The concentration of nickel carbonyl in the chamber could be calculated from the figures for the rate of flow of air through the bubbler containing nickel carbonyl and the vapour pressure of nickel carbonyl at $0^{\circ} \mathrm{C}$. The sampling method probably gives a more accurate estimate of chamber concentrations. Calculations based on these samples indicated that the air passing through the bubbler at speeds varying from 20 to $100 \mathrm{ml}$. per minute contained only 12 volumes \% of nickel carbonyl $(915 \mathrm{~g}$. per $\left.\mathrm{m}^{3}\right)$ instead of 17 volumes $\%\left(1,300 \mathrm{~g}\right.$. per $\left.\mathrm{m}^{3}\right)$ which is the theoretical value for air saturated at $0^{\circ} \mathrm{C}$.

The dose administered is expressed as the "c.t.", i.e., concentration (mg. nickel carbonyl per $\mathrm{m}^{3}$ ) $\mathrm{x} t$ (time of exposure in minutes). The time of exposure was 30 minutes in all but a few experiments when it was reduced to 10 or 20 minutes.

In the majority of the experiments groups of 10 rats were exposed. In the experiments with BAL five of each group of rats were treated with BAL and the other five were untreated. Rabbits were usually exposed in pairs, but in one experiment six were placed in the chamber at one time.

Estimation of Nickel.-Nickel was estimated by a method described by Vaughan (1942). Tissues were digested in nitric and sulphuric acid. The solutions were treated with iodine to oxidize the nickel and a solution of dimethyl glyoxime in ammonium citrate buffer was added. Nickel in the oxidized form produces a soluble orange red colour with dimethyl glyoxime, and the intensity of this was then read at $445 \mathrm{~m} \mu$ on a Unicam D.G. spectrophotometer. Quantities of nickel down to 1 to $2 \mu \mathrm{g}$. in $4 \mathrm{ml}$. of tissue digest could be measured.

Histological Methods.-Tissues were examined from rats that died at different times after exposure to nickel carbonyl, and also from rats killed with chloroform at chosen intervals after exposure. At necropsy the trachea was tied before opening the chest to prevent full collapse of the lungs. At a later stage in the investigation a number of lungs were fixed in full inflation by injecting the fixative into the trachea after opening the chest wall. The trachea was then tied after the lungs had been expanded to fill the pleural cavities. The trachea, lungs, heart, and other mediastinal contents were removed together and placed in fixative. Formol saline and Bouin and Helly's fluid were used as fixatives. Staining methods included Ehrlich's acid haematoxylin and eosin, van Gieson, Heidenhain's azan, and Laidlaw's reticulin stain.

Animals.-Albino rats from the Ministry of Supply Animal Farm, Porton, were used. Rabbits came from a number of different sources. The rabbits weighed $1-1 \cdot 5 \mathrm{k}$.

Nickel Carbonyl.-This was obtained from the Mond Nickel Co., Clydach. It was a water clear liquid and was kept in a glass-stoppered bottle at room temperature. Decomposition with deposition of nickel on the walls of the bottle took place slowly. It was handled with care to avoid contamination of the atmosphere with vapour.

BAL.-The BAL was injected subcutaneously as a $5 \%$ solution in arachis oil, except in one experiment when a freshly prepared aqueous solution was used. 


\section{Results}

Effect of BAL on Rats Exposed to Nickel Carbonyl. -More than 300 rats were exposed to nickel carbonyl for periods of five to 30 minutes (c.t. $\left.17-70 \times 10^{3}\right)$. Immediately after exposure to doses of this order rats appear ill and are very quiet and inactive for an hour or so. They then recover to some extent, but after about 12 hours their condition deteriorates. They sit ruffled and listless in their cages. Some show acute respiratory distress, and at necropsy these are found to have a marked pleural effusion in addition to the extensive pulmonary oedema. When death ensues it usually does so between 18 and 150 hours after exposure. Survivors have symptoms for the first four days and then recover to be free from symptoms by the end of a week.
In comparing the results of treatment the animals were further subdivided according to the dose of nickel carbonyl administered. The results are presented in Table 1.

The experiments demonstrate that when BAL was given before exposure to nickel carbonyl it protected rats completely against a dose of nickel carbonyl approximating to the lethal dose (c.t. 29-38 $\mathrm{x} 10^{3}$ ). However, if the dose is raised (c.t. $70 \times 10^{3}$ ) the protective effect is overcome.

On the other hand when BAL was given to rats at a dosage of 60 to $80 \mathrm{mg}$. per $\mathrm{kg}$. after they had been exposed to nickel carbonyl it did not reduce the mortality but actually increased it. Furthermore, treatment with BAL increased the severity of the signs of poisoning and reduced the time of survival of the fatalities (Table 2).

TABLE 1

EFFECT OF BAL ON THE MORTALITY OF RATS EXPOSED TO DIFFERENT CONCENTRATIONS OF NICKEL CARBONYL

\begin{tabular}{|c|c|c|c|c|c|c|c|c|c|}
\hline \multirow{2}{*}{$\frac{\text { Treatment }}{\mathrm{Nil}}$} & & & & & & \multicolumn{4}{|c|}{$\begin{array}{c}\left.\text { Concentration of Nickel Carbonyl (mg. } / \mathrm{m}^{3}\right) \\
\text { (min.) }\end{array} \times$ Time } \\
\hline & \multicolumn{5}{|c|}{ Animals } & $17-23 \times 10^{3}$ & $29-38 \times 10^{3}$ & $43-58 \times 10^{3}$ & $70 \times 10^{3}$ \\
\hline $\begin{array}{l}\text { Nil } \\
\text { BAL } \\
\text { (Prophylactic) } \\
\text { BAL } \\
\text { (Therapeutic) }\end{array}$ & $\begin{array}{l}\text { No. Exposed } \\
\text { Mortality (\%) } \\
\text { No. Exposed } \\
\text { Mortality (\%) } \\
\text { No. Exposed } \\
\text { Mortality (\%) }\end{array}$ & $\begin{array}{l}\ldots \\
\ldots \\
\ldots \\
\cdots \\
\ldots\end{array}$ & $\begin{array}{l}\cdots \\
\cdots \\
\cdots \\
\cdots \\
\cdots\end{array}$ & $\begin{array}{l}\ldots \\
\cdots \\
\cdots \\
\cdots \\
\cdots\end{array}$ & $\begin{array}{l}\cdots \\
\cdots \\
\cdots \\
\cdots \\
\cdots\end{array}$ & $\begin{array}{l}40 \\
65 \\
- \\
35 \\
74\end{array}$ & $\begin{array}{l}57 \\
77 \\
10 \dagger \\
0 \\
23 \\
83\end{array}$ & $\begin{array}{c}76 \\
84 \\
25 \ddagger \\
44 \\
35 \S \\
100\end{array}$ & $\begin{array}{r}10 \\
100 \\
10 \\
80 \\
- \\
-\end{array}$ \\
\hline
\end{tabular}

The total dose of BAL given to each treated rat was $60-80 \mathrm{mg}$. per $\mathrm{kg}$. In the early experiments this was administered in one or more doses at intervals of one-half to one hour starting immediately after exposure and for periods up to four hours after exposure. The results of treatment were so unsatisfactory that few rats survived for 24 hours or longer and there was no point in continuing treatment beyond the first few hours.

For experiments on the prophylactic value of BAL a dose of 40 or $80 \mathrm{mg}$. per $\mathrm{kg}$. was injected 30 minutes before starting the exposure to nickel carbonyl. Those rats receiving only $40 \mathrm{mg}$. per $\mathrm{kg}$. were given a further dose of the same size after exposure. They were equally well protected.

The rats could therefore be divided into three groups: (1) untreated rats; (2) those receiving BAL before exposure, including some who also received more after exposure (prophylactic treatment); (3) those receiving BAL after exposure (therapeutic treatment).
Effect of BAL on Rabbits Exposed to Nickel Carbonyl.-Fifty-two rabbits were exposed to nickel carbonyl, usually in pairs. The c.t. was 10-37 $\times 10^{3}(\mathrm{t}=10-30$ minutes $)$. One animal of each pair

TABLE 2

EFFECT OF BAL ON SURVIVAL TIME OF RATS AFTER EXPOSURE TO NICKEL CARBONYL*

\begin{tabular}{|c|c|c|c|}
\hline & $\begin{array}{l}\text { No } \\
\text { BAL }\end{array}$ & $\begin{array}{l}\text { BAL Tr } \\
(60-80 n\end{array}$ & $\begin{array}{l}\text { atment } \\
\text { lg. } / \mathrm{kg} \text {.) }\end{array}$ \\
\hline & & $\begin{array}{l}\text { Prophy- } \\
\text { lactic }\end{array}$ & $\begin{array}{l}\text { Thera- } \\
\text { peutic }\end{array}$ \\
\hline $\begin{array}{l}\text { Total number of rats } \\
\text { dying } \\
\text { Deaths on }\left\{\begin{array}{l}1 \text { st day } \\
2 \text { nd day. } \\
3-6 \text { th day }\end{array}\right. \\
\text { Average survival time } \\
\text { in days } \ldots\end{array}$ & $\begin{array}{l}64 \\
27(42 \%) \\
7 \\
30 \\
2 \cdot 3\end{array}$ & $\begin{array}{l}11 \\
2 \\
3 \\
6 \\
\end{array}$ & $\begin{array}{l}35 \\
32(91 \%) \\
2 \\
1 \\
1 \cdot 2\end{array}$ \\
\hline
\end{tabular}


was treated with BAL and the other was untreated : BAL was given as a $5 \%$ solution in arachis oil. A dose of $30 \mathrm{mg}$. per $\mathrm{kg}$. was given one hour after exposure and was followed by $15 \mathrm{mg}$. per $\mathrm{kg}$. given consecutively at five, $20,26,44$, and 50 hours after exposure.

The mortality rate of rabbits treated with BAL is less than that of untreated rabbits although this difference is not statistically significant. The survival time of fatal cases was greater in the treated than in the untreated animals. The results of this experiment are summarized in Table 3. found in the lungs, liver, and brain of three rats killed immediately after exposure are shown.

The amount of nickel found in the lungs at various times is given in Table 5. These figures are expressed as micrograms of nickel found in both lungs of the rat per $1,000 \mu \mathrm{g}$. of nickel inhaled. This adjustment is necessary since different groups of rats were given different exposures, as shown in Table 1. The adjustment is not a strictly accurate one because it was found that in rats killed immediately after exposure, proportionately more nickel had been retained by the rats exposed to the smaller

TABLE 3

MORTALITY RATE AND SURVIVAL TIME IN RABBITS EXPOSED TO NICKEL CARBONYL (C.T. $=10-37 \times 10^{3}$ ) WITH AND WITHOUT SUBSEQUENT BAL TREATMENT

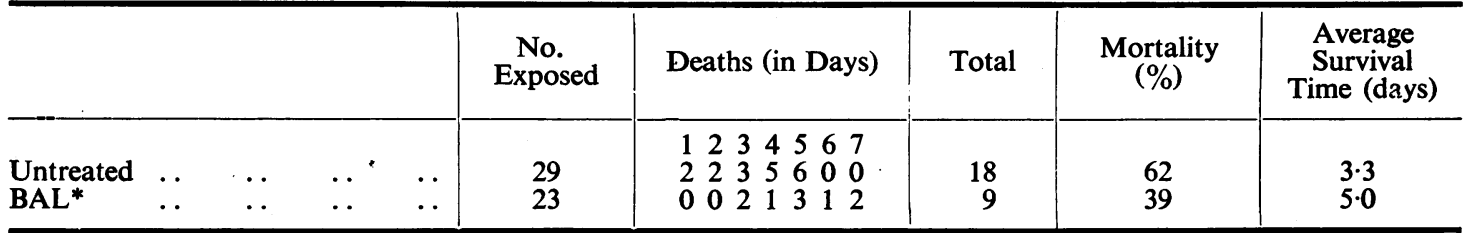

$105 \mathrm{mg} . / \mathrm{kg}$. in divided doses during the first 48 hours after exposure.

*Difference between treated and untreated is not significant : $\chi^{2}=1 \cdot 86, P=0 \cdot 17$.

Fate of Inhaled Nickel.- The distribution of nickel in the tissues of the rat was followed by killing animals at various times after exposure to nickel carbonyl and analysing the tissues for nickel. Assuming the air intake of a rat to be $120 \mathrm{ml}$. per minute (Gaddum, 1948) the amount of nickel that is inhaled by a rat exposed to known concentrations of nickel carbonyl can be calculated. When rats were killed immediately after an exposure of $\mathbf{3 0}$ minutes, the nickel found in the lungs was only 5 to $10 \%$ of the nickel calculated to have been inhaled. Much of the nickel may have been exhaled. Landahl and Herrmann (1950) in an experiment on man put the figure for hydrogen cyanide lost by exhalation as $58 \%$ of the intake.

Considerable amounts of nickel are found in the liver of rats immediately after exposure, indicating a rapid removal of nickel from the lungs. This is illustrated by Table 4 where the amounts of nickel

TABLE 4

NICKEL CONTENT OF RAT TISSUES IMMEDIATELY AFTER 30-MINUTE EXPOSURE TO NICKEL CARBONYL (C.T. $\left.=16 \times 10^{3}\right)$

\begin{tabular}{|c|c|c|c|c|c|}
\hline & & & \multicolumn{3}{|c|}{$\begin{array}{c}\text { Amount of Nickel in Whole } \\
\text { Organ }(\mu \mathrm{g} .)\end{array}$} \\
\hline & & & Lung & Liver & Brain \\
\hline $\begin{array}{ll}\text { Rat } & 1 \\
\text { Rat } & 2 \\
\text { Rat } & 3\end{array}$ & $\begin{array}{l}\cdots \\
\cdots \\
\ldots\end{array}$ & $\begin{array}{l}\cdots \\
\cdots \\
\cdots\end{array}$ & $\begin{array}{l}104 \\
109 \\
118\end{array}$ & $\begin{array}{l}44 \\
73 \\
61\end{array}$ & $\begin{array}{l}17 \\
17 \\
11\end{array}$ \\
\hline
\end{tabular}

concentrations of nickel carbonyl, but this discrepancy is small in comparison with the change in the nickel content of organs found within comparatively short intervals of time after exposure. When the nickel content of the lungs, corrected for

TABLE 5

AMOUNT OF NICKEL* RECOVERED FROM LUNGS OF RATS KULED AT DIFFERENT TIMES AFTER EXPOSURE TO NICKEL CARBONYL

\begin{tabular}{c|c|c|c}
\hline $\begin{array}{c}\text { Hours } \\
\text { after } \\
\text { Exposure }\end{array}$ & $\begin{array}{c}\text { No. } \\
\text { of } \\
\text { Specimens }\end{array}$ & $\begin{array}{c}\text { Ni }(\mu \mathrm{g.}) \\
\text { Mean }\end{array}$ & $\begin{array}{c}\text { Standard } \\
\text { Error of } \\
\text { Means }\end{array}$ \\
\hline 0 & 15 & 84 & $\pm 5 \cdot 2$ \\
1 & 11 & 90 & $\pm 3 \cdot 3$ \\
4 & 5 & 69 & $\pm 2 \cdot 2$ \\
18 & 8 & 30 & $\pm 1 \cdot 1$ \\
24 & 6 & 23 & $\pm 2 \cdot 5$ \\
48 & 3 & 18 & $\pm 1 \cdot 2$ \\
168 & 3 & 14 & $\pm 1 \cdot 7$ \\
\hline
\end{tabular}

*Nickel $(\mu \mathrm{g})$ in whole lung per $1,000 \mu \mathrm{g}$. inhaled.

the dose inhaled, is plotted against the time after exposure (Fig. 2), it is seen that there is a rapid loss of nickel from the lungs during the first 24 hours, and after this removal is much slower and is still incomplete after seven days.

The amounts of nickel in the liver and brain of rats, also corrected for dosage, are given in Table 6. During the period when the lungs are losing nickel rapidly there is a fall rather than a rise in the amount 


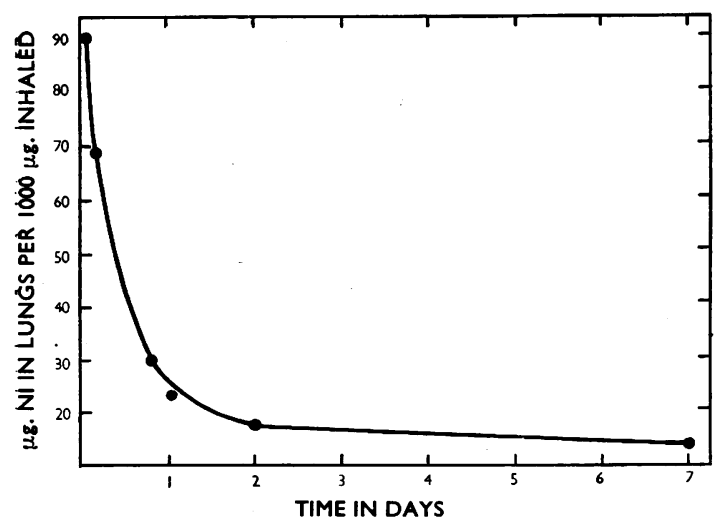

FIG. 2.-Graph showing the rate of decrease in nickel content of rat lungs after exposure to nickel carbonyl.

of nickel in the liver. Further, there does not seem to be any accumulation of nickel in the brain of rats during the first two days.

TABLE 6

RELATION OF TIME AFTER EXPOSURE TO NICKEL CONTENT* OF RAT TISSUES

\begin{tabular}{c|c|c|r}
\hline \multirow{2}{*}{$\begin{array}{c}\text { Time after } \\
\text { Exposure } \\
\text { (in hours) }\end{array}$} & \multicolumn{2}{|c}{ Nickel Content of Organs } \\
\cline { 2 - 4 } & Lung & Liver & \multicolumn{1}{|c}{ Brain } \\
\hline 1 & $90 \pm 3 \cdot 9(11) \dagger$ & $42 \pm 8 \cdot 3(7)$ & $16 \pm 1 \cdot 7(3)$ \\
4 & $69 \pm 2 \cdot 7(5)$ & $16 \pm 3 \cdot 4(7)$ & $9 \pm 1 \cdot 0(6)$ \\
24 & $23 \pm 2 \cdot 5(6)$ & $8 \pm 1 \cdot 4(8)$ & $13 \pm 3 \cdot 3(6)$ \\
48 & $18 \pm 1 \cdot 2(3)$ & $4 \pm 1 \cdot 3(5)$ & $6 \pm 1 \cdot 7(3)$ \\
\hline
\end{tabular}

*Micrograms nickel $(\mu \mathrm{g})$ in the whole organ per 1,000 $\mu \mathrm{g}$ inhaled. Results as means and standard errors.

†Figures in brackets $=$ number of animals.

In rabbits there is no evidence of any remarkable accumulation of nickel in the brain. The amounts found in the brains of six rabbits between the third and fifth day after a lethal dose of nickel carbonyl were respectively, $0.0,0.0,1.5,1.5,4.6$, and $4.6 \mu \mathrm{g}$. per g. BAL treatment did not affect the amount of nickel in the brain, for the amounts found in the brains of five rabbits treated but otherwise comparable were $0 \cdot 0,0 \cdot 0,1 \cdot 5,3 \cdot 1$, and $3 \cdot 1 \mu \mathrm{g}$. of nickel per $\mathrm{g}$.

Pathology.-Tissues for histological examination were taken from 80 rats dying or killed at different times after exposure to nickel carbonyl and from six rabbits that died.

Rat Lungs.-Five rats died within two hours of the end of the exposure. Three had gross pulmonary oedema, one had a minor degree of oedema associated with a pre-existing bronchiectasis, and one had widespread capillary haemorrhages.
Four rats were killed three hours after exposure. They showed marked capillary congestion but only slight pulmonary oedema usually confined to isolated lobules. However, the interstitial tissue of the lung especially round the bronchi and large blood vessels was oedematous, and the lymphatics were dilated (Fig. 3). The most striking pathological findings at this stage were focal haemorrhages (Fig. 4). Some haemorrhages consisted merely of a leak of small numbers of red cells into an alveolus : others were much larger and extended to fill many alveoli with blood cells. The haemorrhagic lesions were larger and more numerous in those rats that had been treated therapeutically with BAL.

The lesions remained much the same for the next nine to 12 hours. Between 15 and 24 hours after exposure a marked change took place. Pulmonary oedema increased considerably and by the end of 24 hours the alveoli were filled with a proteincontaining fluid. Some lobes of the lung were more seriously affected than others, and oedematous lobes were airless except for some widely dilated respiratory bronchioles and alveolar ducts (Fig. 5). Oedema of the interstitial tissue and dilatation of the lymphatics was still present. The oedema persisted through the second and third day, and all animals dying during this period showed massive pulmonary oedema. The more robust animals that survived for this length of time and were deliberately killed showed a less severe degree of oedema that was patchy in distribution. While no distinction could be made between the lesions in treated and untreated rats that died, there were differences seen in the lungs of those killed at this period. Those rats that had received BAL therapeutically always had more severe oedema and more extensive haemorrhages. The one rat treated prophylactically and killed at this stage had very severe pulmonary oedema.

Damage to the bronchi and bronchioles was very slight at all stages. The mucosa was occasionally seen to be lifted on a bleb of oedema and the cells might sometimes appear pale and their outline ragged, but true desquamation did not occur.

From the fourth day onwards the pulmonary oedema regressed, persisting only in isolated lobules. Areas of atelectasis were left, especially at the apices and beneath the pleura. At this stage there was a considerable invasion of the alveoli by neutrophil leucocytes, though on a less extensive scale than in a true pneumonic consolidation. The areas of haemorrhage and collapse became very cellular with the appearance of neutrophils, lymphocytes, macrophages, fibroblasts, and reticulum cells. Within a few more days many of the alveoli filled with young connective tissue and reticulin fibres (Fig. 6). 


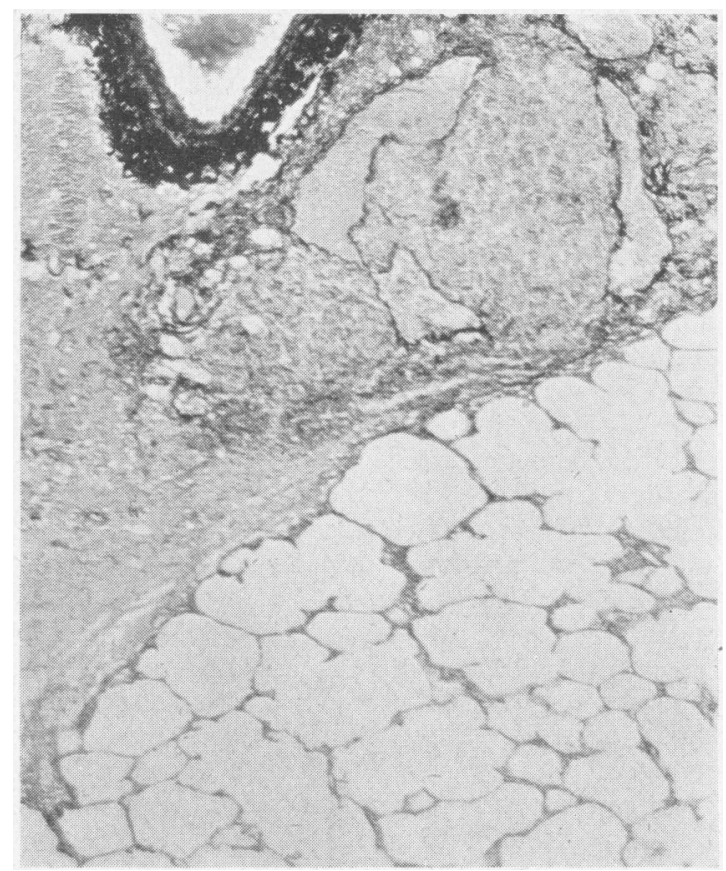

Fig. 3.-Rat lung. Three hours after exposure to nickel carbonyl. Interstitial oedema and dilatation of lymphatics. Heidenhain's azan. $\times 80$.
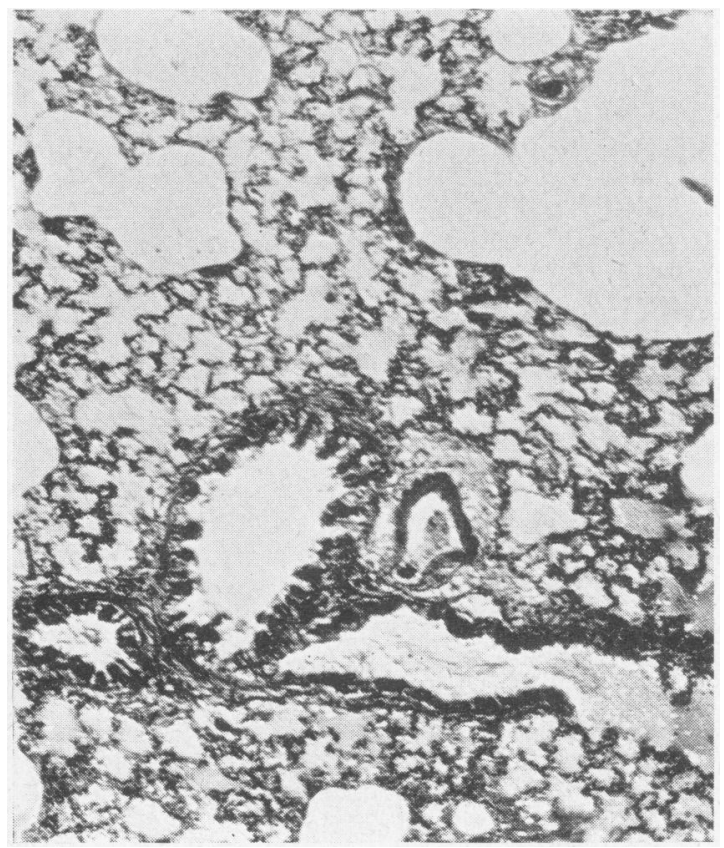

FIG. 5.-Rat lung. Twenty-four hours after exposure to nickel carbonyl. Fully developed pulmonary oedema. Heidenhain's azan. $\times 80$.

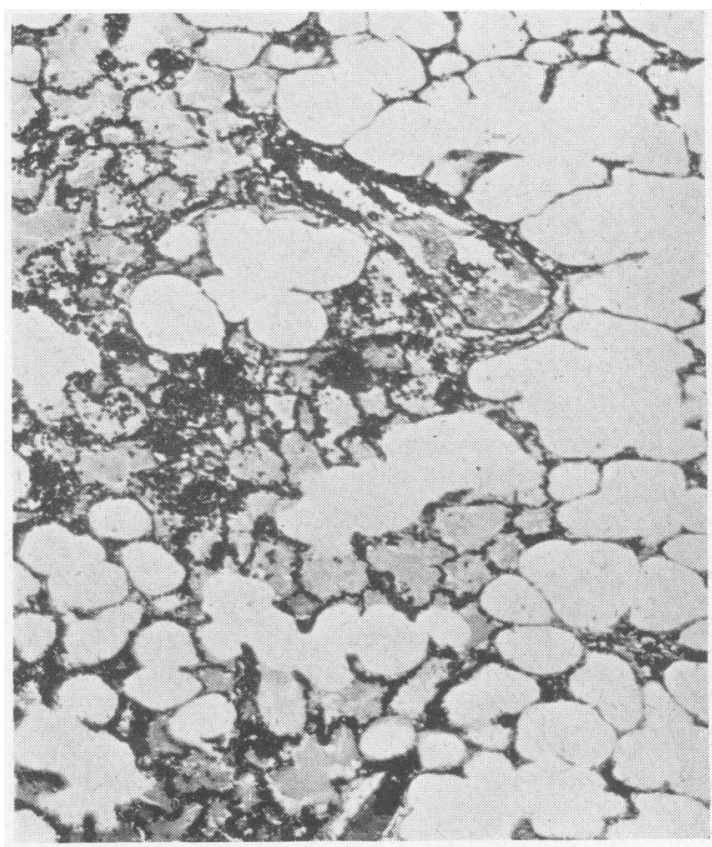

FIG. 4.-Rat lung. Three hours after exposure to nickel carbonyl. Capillary haemorrhages and slight focal oedema. Heidenhain's azan. $\times 80$.

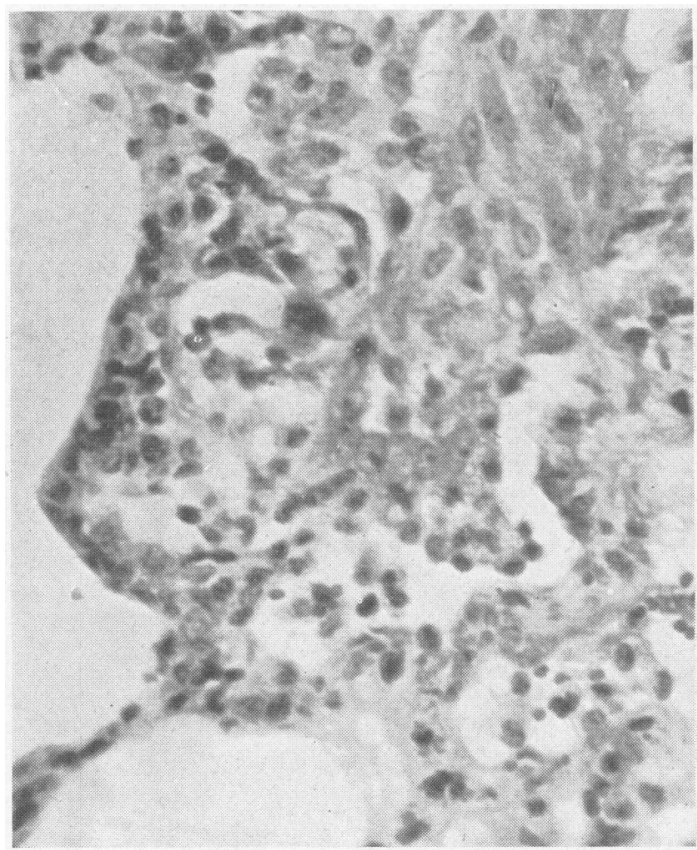

Fig. 6.-Rat lung. Ten days after exposure to nickel carbonyl. Young connective tissue growing into collapsed alveoli. Ehrlich's haematoxylin and eosin. $\times 400$. 


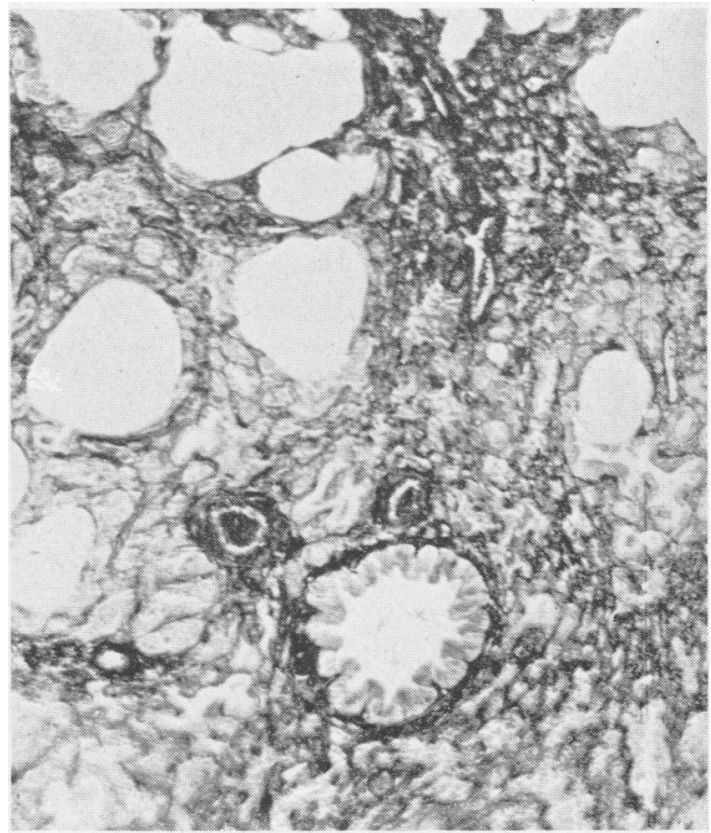

FIG. 7.-Rat lung. Ten days after exposure to nickel carbonyl. Area of collapse and cellular proliferation with large air spaces. Heidenhain's azan. $\times 80$.

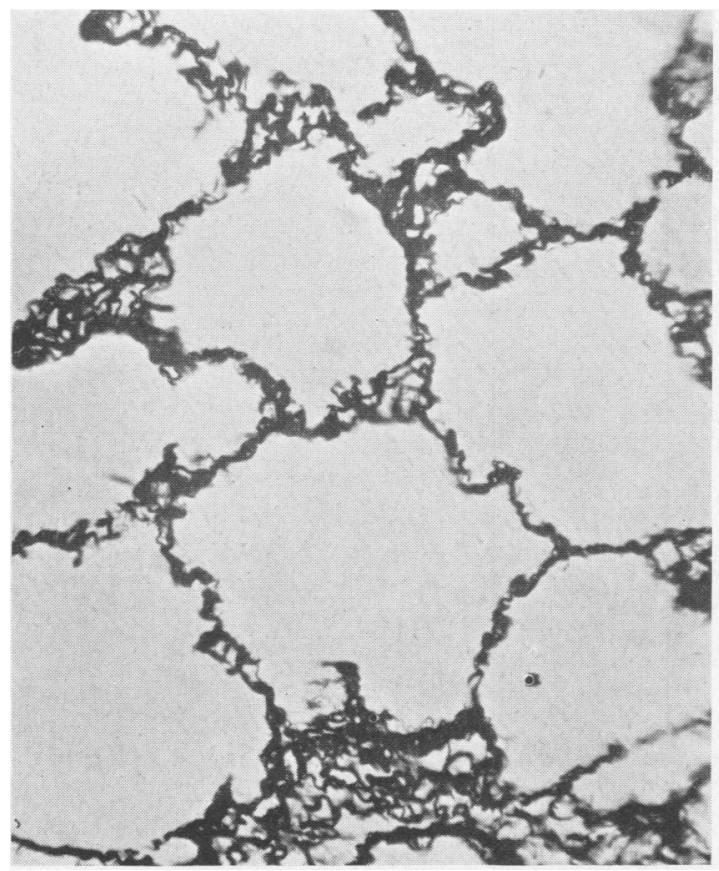

FIG. 9.-Rat lung. Three months after exposure to nickel carbonyl showing increase in number and thickness of fibres in alveolar wall (cf. with Fig. 10). Laidlaw's reticulum method. $\times 250$.

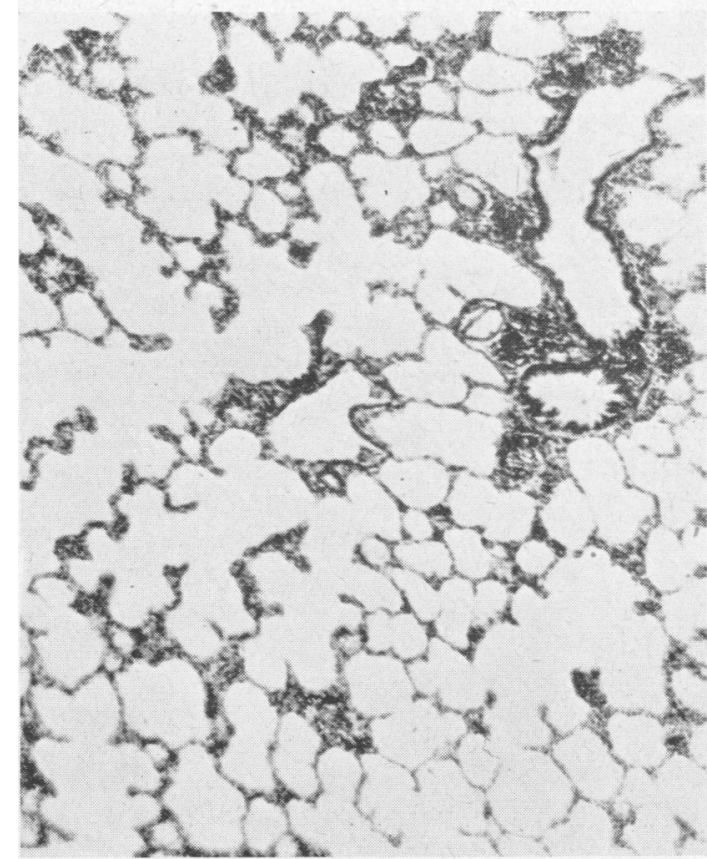

FIG. 8.-Rat lung. Ten days after exposure to nickel carbonyl. Expanded portion of lung showing thickened alveolar septa. Heidenhain's azan. $\times 80$.

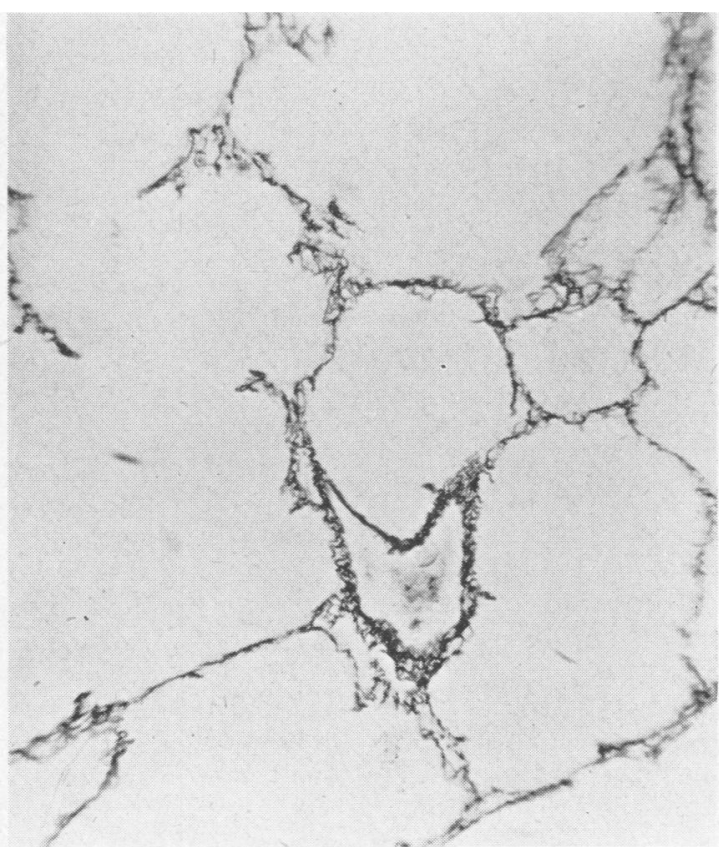

FIG. 10.-Rat lung Control showing thickness and distribution of fibres in normal lung for comparison with Fig. 9. Laidlaw's reticulum method. $\times 250$. 
Collagen, as shown by van Gieson stain, had not yet appeared, but parts of the lung were made up of cellular aggregations pierced by large air spaces (Fig. 7). In the expanded part of the lung the normal thin alveolar wall was replaced by a thick cellular and fibrillary structure of young connective tissue and reticulin fibres (Fig. 8). At this stage no differences were observed between the BAL treated and untreated rats, but there were very few treated animals that died or survived to be killed for examination at this stage.

Tissues were examined from rats that survived the original acute lesion and were killed at intervals up to several months after exposure. The extent of the original lesions were presumably less than in those animals that had succumbed. Nevertheless there was extensive diffuse fibrosis in every rat that was examined between one and four months after exposure. There were aggregations of connective tissue throughout the interstitial tissue. The thick collagen fibres that appeared in the alveolar septa (Fig. 9) can be contrasted with the appearance of the fibres in the normal rat lung (Fig. 10). These fibrous changes reached a maximum at about three months and then resolved slowly. This resolution varied from rat to rat, but animals examined a year or more after exposure did not show either excess of fibrous tissue or any other evidence of damage.

Other Rat Tissues.-An examination of liver, kidney, brain, and spleen of rats exposed to a single dose of nickel carbonyl failed to reveal any lesions that could be attributed to the action of nickel carbonyl.

Rabbit Lungs.-The lesions in both the treated and untreated rabbits that died after exposure to nickel carbonyl were essentially the same as those seen in the rat. No material from the surviving animals was examined.

\section{Discussion}

The observations made on rats and rabbits poisoned by inhalation of nickel carbonyl leave little room for doubt that the cause of death in these animals is the acute pulmonary lesion. There is widespread alveolar oedema associated with a varying degree of capillary haemorrhage and atelectasis. No cerebral lesions were seen and no chemical evidence was obtained of any significant accumulation of nickel in the brain of rats and rabbits. Armit concluded from his experiments with animals that nickel, which was deposited in the lungs, found its way to the adrenals and brain in amounts sufficient to produce lesions in these organs. This conclusion receives some support from the descriptions of petechial haemorrhages and degenerative changes in the brain in human cases of poisoning (Mott, 1907; Amor, 1932; Brandes, 1934). There is no doubt that much of the nickel is rapidly removed from the lungs and, as Armit has shown, some of this goes to the brain, liver, and other organs. But, as seen in Table 6, the maximum level of nickel in the brain is always much lower than that reached in the lung and this maximum is reached in the first hour. There is no progressive accumulation of nickel in the brain. The lesions occasionally found by others in the brain in nickel carbonyl poisoning can probably be ascribed to anoxia due to the defective aeration of blood in the oedematous lung, rather than to the direct action of nickel. Similar lesions in the brain have been reported in phosgene poisoning in which anoxia is also a feature.

As the figures in Table 5 indicate, there is an initial high concentration of nickel in the lung. It may be necessary for such concentrations to be attained in order that a progressive and irreversible change can be produced in the lungs. However, this high concentration of nickel has been removed before the full effects of its action become evident, for pulmonary oedema does not become really severe until the end of the first 24 hours after exposure. It seems likely that the nickel which remains in the lung at a more or less constant level from the end of the first day onwards (Fig. 2) is combined with some part of the cells of the vascular endothelium essential for normal function. The effect of the initial high concentration of nickel could then be explained by assuming that a high extracellular concentration is necessary in order to allow even small quantities to penetrate the cell. The small amount of nickel reaching the interior of the endothelial cells remains there, while the extracellular nickel is rapidly removed from the lung. Although the greater part of the nickel never gained access to cells, it was effective in producing the right physical conditions for the entry of some nickel into the cells of the lung capillaries.

An examination of the lungs within a few hours of exposure to nickel carbonyl shows no alveolar oedema, but there is unmistakable evidence of damage in the form of oedema of the interstitial tissue of the lungs. The amount of fluid in the lungs does not increase much during the first 12 hours but thereafter the alveoli rapidly fill with fluid. The term "pulmonary oedema" is used conventionally to describe the state of the lungs when the alveoli are filled with fluid. This leads to an artificial distinction between the lungs of an animal before and after the filling of the alveoli, and has resulted in a failure to recognize the importance of the earlier changes that lead up to the final spectacu- 
lar disaster of pulmonary oedema. The observations on nickel carbonyl poisoning support the conclusion reached by Shaw Dunn (1918), in his study of phosgene poisoning, that the primary action of lung irritants is on the capillary endothelium. Leakage of plasma from the capillaries begins soon after exposure, but for many hours much of the fluid infiltrates the connective tissue of the lung and is removed by the normal mechanism of drainage by lymphatics and veins which can keep pace with the exudation of fluid. However, if the damage to the capillary wall is progressive more fluid and more protein will pass through the capillary wall. The presence of protein in the exudate is an embarrassment, for as Courtice and Phipps (1946) have shown, removal of fluid containing much protein is slower than fluid that is low in protein. Once fluid begins to collect in the alveoli entry of air is impeded, anoxia develops and further affects the permeability of the capillary wall so that the severity of the pulmonary cedema rapidly increases. If the animal does not die of anoxia the mechanism for absorption of oedema fluid continues to operate and the oedema gradually clears up over a period of some days. In animals surviving exposure to nickel carbonyl severe and extensive lung fibrosis frequently develops in the damaged lungs.'

There is some evidence that the production of pulmonary oedema by the highly active nickel in nickel carbonyl may be due to an action on the enzymes of the capillary endothelium. A number of the different compounds that produce pulmonary oedema in animals share the property of reacting with sulphydryl groups. This has been shown for phosgene by Barron, Bartlett, Miller, and Meyer (1945), and Potts, Simon, and Gerard (1949), for $\alpha$-naphthyl thiourea (A.N.T.U.) by Meyer and Karel (1948), and for alloxan by Lazarow (1947). The toxic effects of heavy metals on biological systems have been attributed to the formation of mercaptides with the sulphydryl groups of the protein component of cellular enzymes (Gilman, Philips, Allen, and Koelle, 1946) and this has been demonstrated for a large number of heavy metals by Barron and Kalnitsky (1947). There are no reports of the inhibition of sulphydryl-containing enzymes by nickel salts, but it has been shown that nickel has an affinity for the sulphydryl groups of cysteine (Michaelis and Barron, 1929; Libenson, 1945) and Griffith, Pavcek, and Mulford (1942) reported that the addition of cysteine to the diet decreased the oral toxicity of nickel salts in rats. We have found that nickel salts form insoluble precipitates with BAL in vitro. The rational for BAL treatment is that if the nickel ion has a greater affinity for the sulphydryl groups offered by the
BAL than for the sulphydryl groups of the tissues, nickel will be removed from the tissues to form with BAL a stable and non-toxic complex. In the rat the combination of nickel with the tissues appears to be too stable to be reversed by BAL. If, however, BAL is 'given before exposure to nickel carbonyl, the BAL seems to be able to compete with the tissues for the nickel and afford some protection. If the dose of nickel carbonyl is further increased this protective action is overwhelmed. In the rabbit BAL is of some value in treatment, suggesting that BAL can remove nickel from combination with the tissues in the rabbit but not in the rat. Indeed, in the rat, the administration of BAL after exposure to nickel carbonyl has a deleterious effect on the lung oedema.

The adverse effect when BAL is given to rats after exposure to nickel carbonyl may be the result of a summation of the effects of two poisons, BAL and nickel. BAL is an effective inhibitor of certain metallo-enzymes (Webb and van Heyningen, 1947 ; Barron, Miller, and Meyer, 1947). In the rat, where the BAL given therapeutically does not reverse the effect of nickel the animal is then at the disadvantage of having sulphydryl-containing enzymes inhibited by nickel and metallo-enzymes inhibited by BAL. Against this hypothesis it should be pointed out that the rat dies of an exacerbation of its lung lesion and does not present the overt symptoms of BAL poisoning (Stocken and Thompson, 1949). In this laboratory it has been found that the kidney lesions produced in rats by the subcutaneous injection of nickel sulphate are aggravated by BAL treatment. The deleterious effect of BAL in these cases is also exerted on the primary lesion and is not a direct manifestation of the toxic effect of BAL as seen in the healthy animal.

The results of treating rats and rabbits with BAL does not give any direct guide to the possible value of BAL in the treatment of nickel carbonyl poisoning in man. It is not known whether man would respond adversely as does the rat or favourably as the rabbit.

The possibility remains that other thiols may be more effective in the treatment of nickel carbonyl poisoning. The introduction of BAL resulted from intensive research directed to a particular endthe discovery of an antidote for lewisite poisoning. The subsequent discovery that BAL was the most effective thiol for the treatment of mercury poisoning as well as arsenic poisoning led to its empirical use in poisoning by other metals. There is some evidence that BAL is not always the best thiol to use. Thus Barron and Kalnitsky (1947) found that the $1: 3$ dithiols were better than BAL for reversing the cadmium inhibition of muscle succinic oxidase, and 
Harvey, Tatum, and Himmelfarb (1947) reported that thiosorbitol gave considerable protection in poisoning with $\alpha$-naphthyl thiourea whereas BAL had an adverse effect. The present work emphasizes the need for precise information on the mode of action of nickel on enzyme systems, and indicates the possible dangers in the empirical use of BAL in cases of poisoning by nickel carbonyl.

\section{Summary}

Rats and rabbits were exposed to the inhalation of nickel carbonyl of known concentrations.

The animals either died of acute pulmonary oedema within a few days or recovered to develop pulmonary fibrosis, maximal at three months and gradually resolving.

Only $5-10 \%$ of the inhaled nickel was found in the lungs. Nickel is rapidly translocated in the body and is not firmly retained by the tissues.

In rats, BAL at a dose of $60-80 \mathrm{mg}$. per kg., given therapeutically had little effect except at one level of nickel carbonyl where significantly fewer rats survived.

In rats, BAL given prophylactically had some protective action against the lower doses of nickel carbonyl.

In rabbits, BAL given after exposure to nickel carbonyl, reduced the mortality rate and increased the survival time, but these effects were not sufficiently great to be significant with the number of animals employed.

\section{REFERENCES}

Amor, A. J. (1932). J. Industr. Hyg., 14, 216.

Armit, H. W. (1907). J. Hyg., Camb., 7, 525.

(1908). Ibid., 8, 565.

Barron, E. S. G., Bartlett, G., Miller, Z. B., and Meyer, J. (1945). Fasciculus on Chemical Warfare Medicine. Vol. 2, p. 151. National Research Council, Washington.

- and Kalnitsky, G. (1947). Biochem. J., 41, 346. .

Brandes, W. W. (1934). J. Amer. med. Ass., 102, 1204. 87, Suppl., p. 119.

Courtice, F. C., and Phipps, P. J. (1946). J. Physiol., Lond., 105, 186. Dunn, J. Shaw (1918). Report No. 9. Chemical Warefare Medical Committee, p. 21 .

Gaddum, J. H. (1948). " "Pharmacology," 3rd ed., p. 305. London.

Gilman, A., Philips, F. S., Allen, R. P., and Koelle, E. S. (1946). J. Pharmacol., 87, Suppl., p. 85 .

Griffith, W. H., Pavcek, P. L., and Mulford, D. J. (1942). J. Nutrit., 23, 603 .

Harvey, T. S., Tatum, H. J., and Himmelfarb, S. (1947). J. Pharmacol., $90,348$.

Landahl, H. D., and Herrmann, R. G. (1950). Arch. industr. Hyg., occup. Med., 1, 36.

Lazarow, A. (1947). Proc. Soc. exp. Biol., N.Y., 66, 4.

Libenson, L. (1945). Exp. Med. Surg., 3, 146.

Meyer, B. J., and Karel, L. (1948). J.' Pharmacol., 92, 15.

Michaelis, L., and Barron, E. S. G. (1929). J. biol. Chem., 83, 191.

Mott, F. W. (1907). Arch. Neurol., Lond, 3, 246.

Potts, A. M., Simon, F. P., and Gerard, R. W. (1949). Arch. Biochem. $24,329$.

Stocken, L. A., and Thompson, R. H. S. (1949). Physiol. Rev., 29, 168 .

Vaughan, E. J. (1942). " Further Advances in the Use of the Spekker Photo-Electric Absorptiometer in Metallurgical Analysis", p. 3. Royal Institute of Chemistry Monograph.

Webb, E. C., and Heyningen, R. van (1947). Biochem. J., 41, 74. 